\title{
Protein degradation of black carp (Mylopharyngodon piceus) muscle during cold storage
}

\section{Bao, Yulong}

2020-03-05

Bao , Y , Wang , K, Yang , H, Regenstein , J M , Ertbjerg , P \& Zhou , P 2020 , ' Protein degradation of black carp (Mylopharyngodon piceus) muscle during cold storage ' , Food Chemistry , vol. 308 , 125576 . https://doi.org/10.1016/j.foodchem.2019.125576

http://hdl.handle.net/10138/327309

https://doi.org/10.1016/j.foodchem.2019.125576

cc_by_nc_nd

acceptedVersion

Downloaded from Helda, University of Helsinki institutional repository.

This is an electronic reprint of the original article.

This reprint may differ from the original in pagination and typographic detail.

Please cite the original version. 
Protein degradation of black carp (Mylopharyngodon piceus) muscle during cold storage

Yulong Bao ${ }^{1}$, Keyu Wang ${ }^{1}$, Hongxu Yang ${ }^{1}$, Joe M. Regenstein ${ }^{2}$, Per Ertbjerg ${ }^{3}$, Peng Zhou ${ }^{1 *}$

1. State Key Laboratory of Food Science and Technology, Jiangnan University, 214122, Wuxi, China

2. Department of Food Science, Cornell University, Ithaca, NY 14853-7201, USA

3. Department of Food and Nutrition, University of Helsinki, 00014 Helsinki, Finland

* Corresponding author: Dr. Peng Zhou, State Key Laboratory of Food Science \& Technology, Jiangnan University, Wuxi, Jiangsu Province 214122, China

Email: zhoupeng@jiiangnan.edu.cn

Tel./fax: +86510 85326012 


\section{Abstract}

The objective of this study was to investigate the effects of storage at different cold temperatures $\left(4,-0.5,-3\right.$ and $\left.-20{ }^{\circ} \mathrm{C}\right)$ on protein degradation and its relationship to structural changes of black carp muscle. At -0.5 and $4{ }^{\circ} \mathrm{C}$, microscopic studies showed that major structural changes included formation of gaps between myofibers and myofibrils, breakage of myofibrils and myofibers, and degradation of sarcoplasmic reticulum. Gel-based proteomic analysis showed that structural changes were accompanied by a degradation of a series of myofibrillar proteins, including titin, nebulin, troponin, myosin, myomesin, myosin binding protein, and $\alpha$-actinin. And a loss of extractable gelatinolytic- and caseinolytic protease activities were also observed. At -3 and $-20^{\circ} \mathrm{C}$, formation of ice crystals was the most noticeable change. The study revealed the major proteins degraded at different locations in the black carp muscle, and the gelatinolytic- and caseinolytic proteases were suggested to contribute to those protein degradation.

Keywords: black carp, myofibrillar protein, muscle structure, zymography, Mylopharyngodon piceus 


\section{Introduction}

After death, fish changes are characterized as: pre-rigor, rigor mortis, end of rigor, autolysis and microbial spoilage. Each stage involves physicochemical processes that modify the muscle structure and consequently alter the meat quality. Fish quality traits are influenced by ante-mortem muscle biochemistry and post-mortem biochemical processes (Delbarre-Ladrat, Chéret, Taylor, \& Verrez-Bagnis, 2006). Despite the complexity of these factors, the end-effect on muscle quality are changes to important structures within the muscle (Hughes, Oiseth, Purslow, \& Warner, 2014). Fish muscles are organized as tissue blocks of myofibers running in parallel and are attached to sheaths of connective tissue (the myocommata). The attachments of myofiber to myocommata and the myofiber to myofiber connections have been reported to be vulnerable during cold storage (Fletcher, Hallett, Jerrett, \& Holland, 1997; Ofstad, Olsen, Taylor, \& Hannesson, 2006; Taylor, Fjaera, \& Skjervold, 2002). Structural changes in fish can also be induced by proteolysis of various cytoskeletal proteins, including titin, nebulin, dystrophin, myosin, tropomyosin and desmin (Delbarre-Ladrat et al., 2006).

Fish generally deteriorate more rapidly after slaughter as compared with terrestrial animals, due to differences such as ultimate $\mathrm{pH}$, water content, endogenous enzymes, and living environment. Fish storage at cold temperatures is widely used to prevent quality deterioration. Chilled storage slows down the growth of microbes, but the endogenous enzymes are still active. Freezing at $-20{ }^{\circ} \mathrm{C}$ or below essentially stops the 
proteolytic activities. However, thawing after frozen storage is generally associated with certain undesirable quality changes, such as tougher texture, higher drip loss and a reduction in water-holding (Ashie, Simpson, \& Ramaswamy, 1997). Superchilling, where fish is partly frozen by lowering the temperature $1-2{ }^{\circ} \mathrm{C}$ below its initial freezing point, has been suggested as a promising method to prolong shelf life. Depending on the temperature actually used, water in the muscle may be partly frozen with superchilling. With superchilling fish generally has longer shelf life as compared with chilled storage, and less freezing-induced damage as compared with frozen storage at $20^{\circ} \mathrm{C}$.

Black carp (Mylopharyngodon piceus) is a carnivorous fish species native to rivers and lakes in East Asia from China to Vietnam. It is one of the main freshwater fish species aquacultured in China. Owing to its large amount of meat, pleasant flavor, and high nutritional value, black carp is of great economic value in the freshwater fish industry (Harimana et al., 2018). In the past it used to be consumed shortly after death. Now the fraction of consumption after cold storage is increasing. Thus it is important to gain some knowledge about the protein degradation and structural changes in black carp muscle during storage. The literature about black carp quality during postmortem storage has mainly focused on freshness indicators, such as K-value, total volatile base nitrogen (TVB-N), growth of microbes and production of biogenic amines (Fan et al., 2016; Fan, Luo, Yin, Bao, \& Feng, 2014; Zou, Wan, Zhong, Li, \& Zhao, 2014). 
Many studies have investigated the microstructural changes in fish muscle during cold storage (Ayala et al., 2010; Fletcher et al., 1997; Ofstad et al., 2006; Taylor et al., 2002), while some focused on post-mortem protein degradation (Kjærsgård \& Jessen, 2003; Li, Li, Hu, Chen, \& Li, 2014). However, few papers have applied proteomics to study the protein degradation in fish muscle and the link between protein degradation and muscle structure has been lacking. Consequently, the aim of this study was to examine the effect of cold storage temperatures $\left(4,-0.5,-3\right.$ and $\left.-20{ }^{\circ} \mathrm{C}\right)$ on protein degradation in black carp muscle and its relationship to muscle structural changes. It was hypothesized that during storage of black carp muscle, endogenous proteases would degrade both major and minor myofibrillar proteins, and subsequently lead to structural changes.

\section{Materials and methods}

\subsection{Chemicals}

All chemicals used were of analytical grade unless otherwise specified. Casein, Epon 812, osmium tetroxide, glutaraldehyde were purchased from Sigma-Aldrich Co. (St. Louis, MO, USA); sodium dodecyl sulphate, acrylamide, bisacrylamide, $\beta$ mercaptoethanol, Triton $\mathrm{X}-100$, gelatin, trypsin (sequencing grade, activity $\geq 150 \mathrm{U} / \mathrm{mg}$ protein) were purchased from Sangon Biotech Co., Ltd. (Shanghai, China). Other chemicals were purchased from Sinopharm Chemical Reagent Co., Ltd. (Shanghai, China). 


\subsection{Fish samples}

Four fresh black carp (Mylopharyngodon piceus) (average weight: $6 \mathrm{~kg}$ ) were obtained from a local aquatic product wholesale market in Wuxi, China. Fish were delivered to the laboratory alive and were killed after head stunning with a sharp blow from a wooden stick. Immediately after death, the white dorsal muscle was cut with a knife into blocks of $2 \times 2 \times 1 \mathrm{~cm}$ and sealed in polyethylene bags. All sampling procedures were done in a walk-in cold room $\left(\sim 4{ }^{\circ} \mathrm{C}\right)$. All the fish blocks were mixed and three randomly chosen muscle blocks were used as control samples (Day 0), and the rest were assigned to 4 groups and stored at $4,-0.5,-3$ and $-20^{\circ} \mathrm{C}$, respectively. Temperature of 0.5 and $-3{ }^{\circ} \mathrm{C}$ were achieved using ice-brine mixtures. Analysis of color, $\mathrm{pH}$ TVB-N of the fish muscle were done on days $1,3,6,10,15$, and 21; while for other traits (sodium dodecyl sulphate-polyacrylamide gel electrophoresis (SDS-PAGE), casein zymography, gelatin zymography and microscopic studies), samples were taken on days 3, 6, 12 and 21 days and kept at $-70{ }^{\circ} \mathrm{C}$ until analysis. All the measurements were done at least in duplicate.

\subsection{Determination of freezing point}

The freezing point of black carp muscle was determined using differential scanning calorimetry (DSC). Briefly, muscle samples $(\sim 1.0--3.0 \mathrm{mg})$ were rapidly cooled to $40{ }^{\circ} \mathrm{C}$ and held for $5 \mathrm{~min}$, and then heated from -40 to $10^{\circ} \mathrm{C}$ at $0.5^{\circ} \mathrm{C} / \mathrm{min}$. The freezing point was determined based on the thermograms as described by Liu, Liang, Xia, Regenstein, \& Zhou (2013). The freezing point was determined to be $\sim-0.8{ }^{\circ} \mathrm{C}$ 
(supplementary Fig. 1).

\subsection{Determination of color}

Samples were equilibrated at $22{ }^{\circ} \mathrm{C}$ for $1 \mathrm{~h}$ before color measurements. The $\mathrm{L}^{*}$ (lightness), a* (redness/greenness) and b* (yellowness/blueness) values were measured with a Minolta Chroma meter CR-400 (Minolta Camera Co. Ltd., Osaka, Japan) using a D65 illuminant, and the diameter of measuring aperture was $8 \mathrm{~mm}$. For each sample, $\mathrm{L}^{*}, \mathrm{a}^{*}$ and $\mathrm{b}^{*}$ values were measured at 6 randomly chosen spots on the surface.

\subsection{Determination of $\mathrm{pH}$}

Fish muscle ( $\sim 10 \mathrm{~g})$ was homogenized (13500 rpm, $1 \mathrm{~min})$ with $10 \mathrm{~mL}$ cold distilled water using a T18 Basic Ultra-Turrax homogenizer (IKA Werke GmbH \& Co., KG, Staufen, Germany) and the $\mathrm{pH}$ measured at $\sim 4{ }^{\circ} \mathrm{C}$ with a $\mathrm{pH}$ meter (Mettler-Toledo GmbH, Schwerzenbach, Switzerland).

\subsection{Determination of TVB-N}

Fish muscle (2 g) was homogenized (13500 rpm, $1 \mathrm{~min})$ with $20 \mathrm{~mL}$ cold distilled water. The homogenate was centrifuged with Heraeus Multifuge XIR centrifuge (Thermo Electron LED GmbH, Osterode, Germany) at $10000 \mathrm{~g}$ for 15 min and the supernatant was used for the determination of TVB-N as described by Liu et al. (2013). The results were expressed as mg nitrogen/100 g muscle. 


\subsection{Light microscopy}

Fish muscle were cut with a knife into small blocks $(5 \times 5 \times 3 \mathrm{~mm})$ and fixed in Bouin solution ( $70 \%$ saturated picric acid, $25 \%$ formaldehyde, and $5 \%$ acetic acid) at $4{ }^{\circ} \mathrm{C}$ for $24 \mathrm{~h}$. After fixation, the samples were dehydrated at $4{ }^{\circ} \mathrm{C}$ with a graded series of ethanol solutions (70-90\% in 5\% increments), followed by incubation with ethanol-xylene (1:1) for $1 \mathrm{~h}$, and then xylene for $1 \mathrm{~h}$. The muscle samples were embedded in paraffin wax and cut longitudinally to the muscle fiber into 5 um thick slices using a microtome (RM2235, Leica Microsystems CMS GmbH, Wetzlar, Germany). The sections were deparaffinized with toluene and rehydrated. These samples were then stained with Masson's trichrome as described by Alizadeh, Chapleau, Lamballerie, \& Le-Bail (2007), with myofibers stained red and connective tissues blue. Finally, all the slides were observed with a light microscope (DM 2000, Leica Microsystems CMS GmbH).

\subsection{Transmission electron microscopy (TEM)}

The microstructure of fish muscle was observed using TEM according to Xu et al. (2016) with some modifications. Fish muscle was cut into small cubes of $1 \times 1 \times 1 \mathrm{~mm}$, and immersed in $2.5 \%$ glutaraldehyde solution for $3 \mathrm{~h}$. After rinsing with $0.1 \mathrm{M}$ sodium phosphate buffer $(\mathrm{pH} 6.8)$ for $3 \times 10 \mathrm{~min}$, the sample was fixed in $1 \%(\mathrm{w} / \mathrm{w})$ osmium tetraoxide for $2 \mathrm{~h}$, followed by washing $(3 \times 10 \mathrm{~min})$ with $0.2 \mathrm{M}$ sodium phosphate buffer. Dehydration was done by incubating (20 min for each step) samples with gradual increased concentration of ethanol $(50-90 \%$ in $10 \%$ increments), followed by incubation in $90 \%$ ethanol/90\% acetone (1:1), and $100 \%$ acetone. All the fixation and 
dehydration was done in a $4{ }^{\circ} \mathrm{C}$ cold room. After dehydration, the samples were infiltrated with a solution containing Epon 812 (Sigma-Aldrich Co., St. Louis, MO, USA) and acetone stepwise in various proportions, ranging from $25 \%$ Epon 812 to $100 \%$ Epon 812. The infiltrated samples were embedded in Epon 812. Ultrathin (90 nm) sections of longitudinal fibers were stained with uranyl acetate and lead citrate and observed with a Hitachi 765 transmission electron microscope (Hitachi Inc., Tokyo, Japan) at $80 \mathrm{kV}$ acceleration voltage. Images were recorded on Kodak electron image film SO-163 (Eastman Kodak Co., Rochester, NY, USA).

\subsection{Casein zymography}

Casein zymography was performed according to Zhang \& Ertbjerg (2018) with some modifications. Fish muscle (5 g) was homogenized (13500 rpm, $1 \mathrm{~min})$ with $15 \mathrm{~mL}$ cold sample buffer (50 mM Tris, $5 \mathrm{mM}$ ethylene diamine tetra acetic acid (EDTA), 10 $\mathrm{mM} \alpha$-thioglycerol, $\mathrm{pH} 7.4)$ and then centrifuged $\left(10000 \mathrm{~g} \times 20 \mathrm{~min}, 4{ }^{\circ} \mathrm{C}\right)$ to get the supernatant. An aliquot of $100 \mu \mathrm{L}$ of the supernatant was thoroughly mixed with 100 $\mu \mathrm{L}$ of sample buffer and kept at $-60{ }^{\circ} \mathrm{C}$ until analysis. The mixtures $(20 \mu \mathrm{L})$ were loaded onto separation gels (containing $12.5 \%$ acrylamide, $0.375 \mathrm{M}$ Tris, $0.1 \%$ casein, $\mathrm{pH} 8.8$ ) and the electrophoresis was done at $75 \mathrm{~V}$ for $3 \mathrm{~h}$ at $4{ }^{\circ} \mathrm{C}$ in running buffer $(25 \mathrm{mM}$ Tris, $192 \mathrm{mM}$ glycine, and $1 \mathrm{mM}$ EDTA, $\mathrm{pH}$ 8.3). After running, the gel was washed with water and incubated overnight at $20{ }^{\circ} \mathrm{C}$ with incubation buffer $\left(4 \mathrm{mM} \mathrm{CaCl}_{2}, 0.1 \% \alpha\right.$ thioglycerol, $50 \mathrm{mM}$ Tris, $\mathrm{pH}$ 7.5). After shaking the gel for $30 \mathrm{~min}$ in buffer to remove calcium (20 mM Tris, $10 \mathrm{mM}$ EDTA, pH 7.0), the gel was stained in Coomassie 
Brilliant Blue G-250 overnight and then destained in distilled water for $5 \mathrm{~h}$ (changes of water every hour). Clear bands in the blue gel indicate caseinolytic protease activity.

\subsection{Gelatin zymography}

Gelatin zymography was done according to Wu et al. (2008) with some modifications. Fish muscle (5 g) was homogenized (13500 rpm, $1 \mathrm{~min})$ with $20 \mathrm{~mL}$ cold sample buffer (1 M Tris, $\mathrm{pH} 8.0$ ), and then centrifuged $\left(10000 \mathrm{~g} \times 20 \mathrm{~min}, 4{ }^{\circ} \mathrm{C}\right)$. An aliquot of $50 \mu \mathrm{L}$ of the supernatant was mixed with $50 \mu \mathrm{L}$ of $2 \times$ SDS sample buffer and kept at $-60{ }^{\circ} \mathrm{C}$ until analysis. The mixtures $(20 \mu \mathrm{L})$ were loaded onto a $5 \%$ separation gel with 1 $\mathrm{mg} / \mathrm{mL}$ gelatin in the gel. The electrophoresis was done at a constant current of $10 \mathrm{~mA}$ for $3 \mathrm{~h}$ at $4{ }^{\circ} \mathrm{C}$. After running, the gel was washed twice with $2.5 \%$ Triton $\mathrm{X}-100$ to remove SDS and rinsed with distilled water. Then the gel was incubated overnight at $37{ }^{\circ} \mathrm{C}$ with incubation buffer ( $50 \mathrm{mM}$ Tris, $5 \mathrm{mM} \mathrm{CaCl}_{2}$, $\mathrm{pH} 8.0$ ) followed by staining with Coomassie Brilliant Blue G-250 for $3 \mathrm{~h}$. The gel was destained in distilled water as above and clear bands in the blue gel indicate gelatinolytic activity.

\subsection{SDS-PAGE and protein identification}

Fish muscle $(1.25 \mathrm{~g})$ was homogenized $(13500 \mathrm{rpm}, 1 \mathrm{~min} \times 2)$ with $25 \mathrm{~mL}$ cold distilled water. The homogenate was mixed with $2 \times$ SDS sample buffer which also contained 5\% $\beta$ - mercaptoethanol. Before electrophoresis, the mixture was boiled for 3 min followed by centrifugation at $10000 \mathrm{~g}$ for $3 \mathrm{~min}$. An aliquot (10 $\mu \mathrm{g}$ protein) of the resulting supernatant was placed in a well and subjected to SDS-PAGE. Electrophoresis 
was done using 3 different separation gels (4, 10 and 15\%) to better resolve proteins over a wide range of molecular weights. After electrophoresis, gels were stained with Coomassie Brilliant Blue R-250 in 50\% (v/v) methanol and 6.8\% (v/v) glacial acetic acid for $1 \mathrm{~h}$, and then destained using 7.5\% (v/v) glacial acetic acid and 5\% (v/v) methanol for about $20 \mathrm{~h}$.

Protein bands from areas of interest in the gels were excised for protein identification. Each gel piece was destained with $400 \mu \mathrm{L} 100 \mathrm{mM} \mathrm{NH}_{4} \mathrm{HCO}_{3} / 30 \%$ acetonitrile. After freeze drying, the gel piece was rehydrated with $5 \mu \mathrm{L} 5 \mathrm{ng} / \mu \mathrm{L}$ trypsin $\left(4{ }^{\circ} \mathrm{C}\right.$ for $\left.60 \mathrm{~min}\right)$. Another $20 \mu \mathrm{L}$ of $25 \mathrm{mM} \mathrm{NH}_{4} \mathrm{HCO}_{3}$ was added to the gel piece and incubated at $37{ }^{\circ} \mathrm{C}$ for $20 \mathrm{~h}$. Resulting tryptic peptides were extracted from the gel matrix using $2 \mathrm{~s}$ sonication in an ultrasonic water bath $(\mathrm{SK} 7200 \mathrm{H}$, Kudos Ultrasonic Instrument Co., Shanghai, China ) in $20 \mu \mathrm{L} 60 \%$ acetonitrile/0.1\%TFA. The peptides extract was freeze dried and rehydrated in $5 \mu \mathrm{L} 60 \%$ acetonitrile/ $0.1 \% \mathrm{TFA}$, and then $1 \mu \mathrm{L}$ of the peptide sample was mixed with $1 \mu \mathrm{L}$ of a saturated solution of 4-hydroxy- $\alpha$-cyanocinnamic acid $(0.7 \mathrm{mg} / \mathrm{mL}$ in $85 \%$ acetonitrile and $0.1 \%$ TFA) and spotted onto a MALDI target and air-dried. The mass spectra were obtained using a M@LDI R mass spectrometer (Waters, Milford, MA, USA) using a delay extraction procedure. Raw data were analyzed using software with the instrument and were obtained as average masses.

Proteins were identified from their peptide mass fingerprints by searching using a locally implemented MASCOT server (www.matrixscience.com) working with the 
NCBI-Prot database (https://www.ncbi.nlm.nih.gov/protein/). Initial search parameters allowed a mass tolerance of $\pm 0.5 \mathrm{Da}$, up to one missed tryptic cleavage, mass changes due to protein modifications (carbamidomethyl modification of cysteine residues and variable oxidation of methionine). The taxonomic search space was restricted to Chordata.

\subsection{Statistical analysis}

Data for $\mathrm{pH}$, color $\left(\mathrm{L}^{*}, \mathrm{a}^{*}, \mathrm{~b}^{*}\right)$, and TVB-N measurements were analyzed using the IBM Statistical Package for the Social Sciences Ver. 20 software (Armonk, NY, USA) using the general linear model. Storage time and storage temperature were included as fixed factors. Tukey honest significant difference test was used to find significant differences at a level of $\mathrm{P}<0.05$ although in some cases a greater significance was obtained and is shown.

\section{Results}

\subsection{Changes of $\mathrm{pH}$, color and TVB-N}

During storage at different cold temperatures, $\mathrm{pH}$, color and TVB-N values of black carp muscle were affected (supplementary Table 1). $\mathrm{pH}$ was only affected by storage time $(\mathrm{P}<0.001)$, and changed from $\sim 6.8$ at day 0 , to $\sim 6.3$ at day 21 . TVB-N is widely used as an indicator of fish freshness. TVB-N was significantly affected by storage time and temperature, and there was a clear interaction between temperature and time $(\mathrm{P}<$ 0.001). TVB-N increased with prolonged storage, and a higher temperature generally 
led to a higher TVB-N values as observed at day 15 and $21\left(-0.5{ }^{\circ} \mathrm{C}\right.$ compared to $\left.20^{\circ} \mathrm{C}\right)$. But up to 10 days of storage, temperature did not affect TVB-N values $(\mathrm{P} \geq$ 0.05). L* values indicates the lightness of black carp muscle and lightness generally increased with storage time and temperature $(\mathrm{P}<0.001)$. Both $\mathrm{a}^{*}$ and $\mathrm{b}^{*}$ values were close to 0 and were significantly affected by storage time and temperature $(\mathrm{P}<0.001)$.

\subsection{Microstructure}

Microscopic images of fresh black carp muscle were obtained (Fig. 1) and longitudinal sections were examined during storage by light microscopy (Fig. 2) and by TEM images (Fig. 3). At day 0, myofibers showed a tight packing surrounded by connective tissues (endomysium) (Fig. 1A). Myofibers were attached to the myocommata as a continuous network of connective tissue (Fig. 1C). TEM showed the structure of myofibrils where normal components (Z-disk, M-line, etc.) of a sarcomere can be seen. In addition, filamentous linkages between myofibrils and sarcoplasmic reticulum surrounding the myofibrils were observed as well (Fig. 1B). The basement membrane is made up of two layers and the internal basal lamina is directly linked to the sarcolemma. At day 0, myofibrils were closely attached to the sarcolemma-basement membrane complex (Fig. 1D).

At $4{ }^{\circ} \mathrm{C}$ gaps formed between myofibers and increased during storage (Fig. 2), and at day 12 and 21, substantial longitudinal breakage within the myofibers occurred. Gaps between myofibers and breakage within fibers was also seen at $-0.5^{\circ} \mathrm{C}$, but to a lesser 
extent, suggesting a more slow development of the structural changes at this temperature. Expansion of inter-myofiber spaces were not clearly observed during frozen storage of samples at -3 and $-20{ }^{\circ} \mathrm{C}$. Ice crystals could be seen in frozen samples and the ice crystals led to a large distortion of the myofibers. The number of ice crystals generally increased with increased storage time, and $-3{ }^{\circ} \mathrm{C}$ samples appeared to have larger ice crystals than $-20^{\circ} \mathrm{C}$ at day 12 and 21 . No significant detachments of myofibermyocommata (supplementary Fig. 2) were observed, but storage at -3 and $-20{ }^{\circ} \mathrm{C}$ appeared to induce a damage to the myocommata area.

TEM images showed the structural changes of frozen muscle at the myofibril level (Fig. 3). For samples stored at -3 and $-20{ }^{\circ} \mathrm{C}$, no major changes were observed. For samples stored at 4 and $-0.5^{\circ} \mathrm{C}$, the inter-myofibrillar spaces generally increased with increasing storage time. At day 21 , storage at $4{ }^{\circ} \mathrm{C}$ led to severe damage of myofibrils, evidenced by breakage of myofibrils near the Z-line and loss of filamentous material (from thick and/or thin filament) within the sarcomere. Another noticeable change was that the sarcoplasmic reticulum between the myofibrils degraded after storage. Discontinued Zdisk at day 21 at $-0.5{ }^{\circ} \mathrm{C}$ suggests degradation of protein structures in or adjacent to the Z-disk, and storage at $-0.5^{\circ} \mathrm{C}$ generally resulted in similar structural changes compared to $4{ }^{\circ} \mathrm{C}$, but to a lesser extent. TEM images showing the attachment of myofibrils to sarcolemma-basement membrane complex are shown in supplementary Fig. 3. At $4{ }^{\circ} \mathrm{C}$, the sarcolemma-basement membrane complex gradually separated from myofibrils and breakage of the complex was observed at day 21 . 


\subsection{Proteolytic enzyme activity}

A clear band in the casein zymogram gel indicated the extractable caseinolytic protease activity, which remains in the muscle after storage. A decrease of band intensity indicates that the protease has been activated and thereafter lost its activity. One band was detected on the casein zymograms (Fig. 4A). In muscle two ubiquitous caplains, $\mu$ - and m-calpain, have been widely studied. And both calpains are caseinolytic. There was a general trend that higher temperatures and longer storage time led to decreased caseinolytic protease activity in the samples stored at $4,-0.5$ and $-3{ }^{\circ} \mathrm{C}$, and no band was visible for samples stored at $4{ }^{\circ} \mathrm{C}$ at days 12 and 21 . Frozen storage at $-20{ }^{\circ} \mathrm{C}$ did not significantly affect the band intensity.

Similar to casein zymography, a clear band in gelatin zymogram indicates gelatinolytic activity. Three major bands were detected and designated as gelatinolytic protease 1, 2 and 3, and one additional band migrating just below protease 2 at day 12 and 21 at $0.5^{\circ} \mathrm{C}$ (Fig. 4B). At 4 and $-0.5^{\circ} \mathrm{C}$, the intensity of the three major bands decreased with increased storage time and the gelatinolytic protease 3 was almost not detectable at day 12 and 21 . At $-3{ }^{\circ} \mathrm{C}$, only a slight decrease of gelatinolytic protease 3 was observed at day 21 . For samples stored at $-20^{\circ} \mathrm{C}$, no observable changes happened during storage for all three proteases.

\subsection{SDS-PAGE and protein identification}


Protein extracts of black carp muscle stored at $4{ }^{\circ} \mathrm{C}$ were separated in 4,10 and $15 \%$ polyacrylamide gels (Fig. 5). In general, no apparent changes occurred during the first 3 days of storage, and thereafter proteolysis and formation of new bands started to be evident. In total, 9 bands (D1 - D9) decreased and 11 bands (I1 - I11) increased in intensity during storage. These bands were then selected for protein identification using MALDI-TOF. The identified changes were mainly related to degradation of myofibrillar proteins, including titin, nebulin, myosin, troponin-T, troponin-I, $\alpha$-actinin, and myomesin. In addition, the sarcoplasmic proteins fructose-bisphosphate aldolase A and endoplasmic reticulum calcium ATPase were found to be degraded during storage (Table 1).

For samples stored at $-0.5,-3$ and $-20{ }^{\circ} \mathrm{C}$, there were no major changes of protein bands throughout storage, except for D2 (nebulin) and I5 ( $\alpha$-actinin) bands at $-0.5{ }^{\circ} \mathrm{C}$ (supplementary Fig. 4). At $-0.5^{\circ} \mathrm{C}$, nebulin decreased during storage, but to a lesser extent than at $4{ }^{\circ} \mathrm{C}$. A new band (I5) identified as $\alpha$-actinin appeared on the gel after 6 days of storage at 4 and $-0.5{ }^{\circ} \mathrm{C}$. However, this band (I5) was not observed at -3 or $20{ }^{\circ} \mathrm{C}$.

\section{Discussion}

Skeletal muscle structures is described as being in a hierarchical form from macro to micro: Muscle is composed of muscle fibres, and a muscle fibre is composed of rodlike myofibrils, which in turn consist of thick and thin filaments. The smallest 
contractile unit of striated muscle is the sarcomere. The extremely ordered structure of a sarcomere is based on the assembly of a large number of protein subunits. Myosin, titin, myosin binding protein $\mathrm{C}$ and $\mathrm{H}$ in thick filaments and actin, nebulin, tropomyosin and troponin complex in thin filament, $\alpha$-actinin and other associated proteins in Z-disks, and myomesin and M-proteins in the M-band (Ertbjerg \& Puolanne, 2017). The degradation of these structural proteins, even to a small extent, could lead to structural changes of the muscle and thereby affect meat quality.

Many of the abovementioned myofibrillar proteins in fish muscle are degraded by endogenous enzymes (e.g., calpains, cathepsins, proteasome) during post-mortem storage (Delbarre-Ladrat et al., 2006). At later stages of cold storage, microbial activity may also lead to protein degradation. The microbial activity was suggested by increased TVB-N with increasing storage time and temperature (supplementary Table 1). The involvement of endogenous enzymes in myofibrillar protein degradation in the present study was indicated by the gradual disappearance or decrease of the caseinolytic protease activity (Fig. 4A). $\mu$-Calpain is generally activated in early post-mortem proteolysis, while m-calpain has been reported to be partially activated later postmortem (Boehm, Kendall, Thompson, \& Goll, 1998; Pomponio et al., 2008). In carp muscle, $\mu$ - and m-calpain are the two dominant isoforms of calpains (Toyohara \& Makinodan, 1989). And m-calpain was able to degrade $\alpha$-actinin in the myofibrils of carp (Tsuchiya \& Seki, 1991). Therefore, the observed caseinolytic protease activated later post-mortem at 4 and $-0.5{ }^{\circ} \mathrm{C}$ was likely to be m-calpain. 
A range of myofibrillar proteins including titin, nebulin, myosin, myosin binding protein, myomesin, $\alpha$-actinin, and troponin-T and -I were found to be degraded during storage of black carp muscle at temperatures above the freezing point (Fig. $5 \&$ Table 1); the degradation of those proteins are likely the major cause for structural changes at the corresponding positions within sarcomeres.

Myosin is the major constituent of myofibrillar proteins, and is made up of two heavy chains and four light chains. Degradation of myosin heavy chain (Li et al., 2014; Wang, Martinez, \& Olsen, 2009) has been reported in fish muscle during storage. Similarly, this study showed proteolysis of myosin heavy chain, and a series of degraded myosin heavy chains were observed in SDS-PAGE. In addition, myosin light chains were also degraded. Titin and nebulin have important roles in organizing sarcomeres. Degradation of titin and nebulin is likely to weaken the thick and thin filaments, respectively. Some minor protein components in thick or thin filaments (myosin binding protein $\mathrm{C}$, troponin-T and -I) were found to be degraded as well (Fig. $5 \&$ Table 1). Myosin, titin, nebulin, myosin binding protein $\mathrm{C}$ and troponin complex together account for a major part of myofibrillar proteins. Proteolysis of these filamentous components in thick and thin filament gradually led to loss of structural integrity between adjacent Z-disks in the myofibril (Fig. 3), which resulted in weakening of myofibers (Fig. 2). $\alpha$-Actinin is a major component of the Z-disk and helps to stabilize the sarcomere structure. It has been found to be released and degraded from the Z-disks in bass and sea trout (Papa, 
Alvarez, Verrezbagnis, Fleurence, \& Benyamin, 1996). When carp myofibrils were incubated with m-calpain, release of both native and digested $\alpha$-actinin was observed (Tsuchiya \& Seki, 1991), indicating the involvement of m-calpain in disorganizing the Z-disk. In this study, degradation of $\alpha$-actinin and activation of caseinolytic protease was accompanied by weakened Z-disks suggested by ruptures at or near Z-disks.

Degradation of other Z-disk associated proteins such as LIM domain binding (LDB) protein may have contributed to the weakened Z-disk, as LDB3 in yellow croaker was found to decrease during storage (Li et al., 2014). Due to weakened Z-disks, breakage of myofibrils were generally near the Z-disk (Fig. 3). The M-line (contains myomesin and M-protein) appears in the central region of a sarcomere and is needed for regular packing of the myosin filaments (Agarkova \& Perriard, 2005). Degradation of myomesin was shown in bull muscle (Wu, Clerens, \& Farouk, 2014), and in fish muscle in this study. Degradation of protein components in the transversal M-line and Z-disk may have facilitated the loss of filamentous materials in thick and thin filaments as shown in Fig. 3.

Inter-myofibrillar spaces increased gradually throughout post-mortem storage of nonfrozen samples. The initial increase was likely due to the swelling of the sarcoplasmic reticulum surrounding the myofibrils. And at the last stages of cold storage of black carp, a strong destruction of sarcoplasmic reticulum was observed. The increased space and broken sarcoplasmic reticulum were also reported in other fish studies (Ayala et al., 2010; Ofstad et al., 1996). Those authors attributed the increased space to degradation 
of inter-myofibrillar links (desmin and M-filaments) and increased osmolarity. Intermyofiber space increased with storage and at $4{ }^{\circ} \mathrm{C}$ the space was generally larger as compared to $-0.5{ }^{\circ} \mathrm{C}$. The formation of actomyosin bonds during rigor reduced the lattice spacing and the transverse shrinkage would be transmitted to the entire fiber through the costameric linkages (Huff-Lonergan \& Lonergan, 2005). The sampling procedures may have contributed to the observed inter-myofiber and inter-myofibrillar spaces. Those increased spaces indicated a more open packing of structural elements, which was related to higher light scattering (Hughes et al., 2014). The relationship between open packing and higher lightness was supported by the observation that lightness generally increased with storage time and temperature $\left(4\right.$ vs. $-0.5{ }^{\circ} \mathrm{C}$, supplementary Table 1).

The breakdown of connective tissue has been related to tissue softening in fish. Two gelatinolytic proteases were detected using gelatin zymography, and the activity decreased after 6 days at 4 and $-0.5{ }^{\circ} \mathrm{C}$ (Fig. 4B), which suggested that the enzymes have been activated, similar to loss of the caseinolytic protease in casein zymography. This was partly supported by the observation that the basement membrane was damaged for samples stored for 21 days at $4{ }^{\circ} \mathrm{C}$. Method for evaluating the proteolytic activity may have an influence on the results. Hernández-Herrero, Duflos, Malle, \& Bouquelet (2003) followed collagenase activity of cod muscle during 9 days of iced storage. Collagenase activity against synthetic substrates generally increased during storage, but when bovine insoluble collagen was used as the substrate, no significant 
changes in collagenase activity were found throughout storage.

When black carp was stored below its freezing point $\left(-0.8^{\circ} \mathrm{C}\right)$ at -3 and $-20{ }^{\circ} \mathrm{C}$, formation of ice crystals during freezing damaged muscle integrity. Different temperatures led to different freezing rate, and freezing rate is known to affect the size and number of ice crystals formed and their distribution among the intra- or extracellular spaces. Those aspects of ice crystals are particularly important in frozen meat as they affect water-holding, texture and surface color (Calvelo, 1981). Alizadeh et al. (2007) reported that pressure shift freezing led to homogeneous and small ice crystals in salmon, while air-blast freezing produced large and irregular ice crystals. The observed difference was very likely due to freezing rates. In the present study, the number of ice crystals at $-3{ }^{\circ} \mathrm{C}$ appeared to be less than at $-20{ }^{\circ} \mathrm{C}$ at initial storage, and during storage at $-3{ }^{\circ} \mathrm{C}$, ice crystals became larger. However, in a study of superchilled salmon stored at $-1.7^{\circ} \mathrm{C}$, Kaale \& Eikevik (2013) found no significant differences in the size of the ice crystals after temperature equalization (day 1). No major changes in protein degradation were observed for storage below the freezing point. Similarly, no significant changes in the SDS-PAGE profiles were observed for grass carp fillets stored at a superchilling temperature of $-3{ }^{\circ} \mathrm{C}$ (Liu et al., 2013). Superchilling temperatures are low enough to significantly suppress bacterial growth, but enzyme reactions and other chemical reactions may take place (Kaale \& Eikevik, 2014). This is partly supported in the present study that TVB-N was suppressed at $-3{ }^{\circ} \mathrm{C}$ compared to higher storage temperatures, while partial activation of caseinolytic- and gelatinolytic 
proteases at a later stage of storage was observed.

One limitation of the present study is that less abundant muscle proteins (hence not stained in the SDS-PAGE gels) were not included in the protein degradation analysis. In muscle, some minor protein components such as desmin and dystrophin have important roles in maintaining the structural integrity. A more advanced proteomic approach would provide additional information to supplement the major findings of this study. And the caseinolytic- and gelatinolytic proteases which seems to contribute to the protein degradation require further identification.

\section{Conclusion}

When the black carp muscle was stored at temperatures above its freezing point, major structural changes occurred at the end of storage. Those changes included a weakening and breakage of myofibrils, increased inter-myofibrillar and inter-myofiber spaces, and breakage of the sarcoplasmic reticulum and the sarcolemma-basement membrane complex. Those structural changes were accompanied by degradation of a range of myofibrillar proteins (titin, nebulin, troponin, myosin, myomesin, myosin binding protein, and $\alpha$-actinin) in different positions of the sarcomere (Z-disk, thick filament, thin filament, M-line). Loss of extractable gelatinolytic- and caseinolytic proteases suggested that they played a role in the protein degradation. In comparison, storage below the freezing point did not induce significant changes in proteolysis, but ice crystals distribution in muscle tissue were found to be different for -3 and $-20{ }^{\circ} \mathrm{C}$, which 
would affect the meat quality. Overall, through gel-based proteomics and TEM images, the present study added new knowledge on the relationship between protein degradation and muscle structural changes in the black carp during storage at different cold temperatures.

\section{Declaration of conflicts of interest}

None.

\section{Acknowledgement}

This research was funded by China Postdoctoral Science Foundation (2019M651707),

Start-up Foundation for Postdoctoral Researcher of Jiangnan University (5818088201190990), and by the National First-class Discipline Program of Food Science and Technology of Jiangnan University (JUFSTR20180201).

\section{Appendix A. Supplementary material}

Supplementary data associated with this article can be found, in the online version.

\section{References}

Agarkova, I., \& Perriard, J. C. (2005). The M-band: an elastic web that crosslinks thick filaments in the center of the sarcomere. Trends in Cell Biology, 15, 477-485.

Alizadeh, E., Chapleau, N., Lamballerie, M. D., \& Le-Bail, A. (2007). Effect of different freezing processes on the microstructure of Atlantic salmon (Salmo 
salar) fillets. Innovative Food Science \& Emerging Technologies, 8, 493-499.

Ashie, I. N. A., Simpson, B. K., \& Ramaswamy, H. S. (1997). Changes in texture and microstructure of pressure-treated fish muscle tissue during chilled storage. Journal of Muscle Foods, 8, 13-32.

Ayala, M. D., Abdel, I., Santaella, M., Martínez, C., Periago, M. J., Gil, F., . . L López Albors, O. (2010). Muscle tissue structural changes and texture development in sea bream, Sparus aurata L., during post-mortem storage. LWT - Food Science and Technology, 43, 465-475.

Boehm, M. L., Kendall, T. L., Thompson, V. F., \& Goll, D. E. (1998). Changes in the calpains and calpastatin during postmortem storage of bovine muscle. Journal of Animal Science, 76, 2415-2434.

Calvelo, A. (1981). Recent studies on meat freezing. In R. Lawrie, Developments in Meat Science, Vol 2. (pp. 125-158). London: Applied Science Publishers.

Delbarre-Ladrat, C., Chéret, R., Taylor, R., \& Verrez-Bagnis, V. (2006). Trends in postmortem aging in fish: understanding of proteolysis and disorganization of the myofibrillar structure. Critical Reviews in Food Science \& Nutrition, 46, $409-421$.

Ertbjerg, P., \& Puolanne, E. (2017). Muscle structure, sarcomere length and influences on meat quality: A review. Meat Science, 132, 139-152.

Fan, H., Liu, X., Hong, H., Shen, S., Xu, Q., Feng, L., \& Luo, Y. (2016). Quality changes and biogenic amines accumulation of black carp (Mylopharyngodon piceus) fillets stored at different temperatures. Journal of Food Protection, 79, 
635-645.

Fan, H., Luo, Y., Yin, X., Bao, Y., \& Feng, L. (2014). Biogenic amine and quality changes in lightly salt- and sugar-salted black carp (Mylopharyngodon piceus) fillets stored at $4{ }^{\circ} \mathrm{C}$. Food Chemistry, 159, 20-28.

Fletcher, G. C., Hallett, I. C., Jerrett, A. R., \& Holland, A. J. (1997). Changes in the fine structure of the myocommata-muscle fibre junction related to gaping in rested and exercised muscle from king salmon (Oncorhynchus tshawytscha) . LWTFood Science and Technology, 30, 246-252.

Harimana, Y., Xue, T., Le, G., Xing, X., Kai, Z., Sun, Y., .. . Tuyishimire, M. A. (2018). Quality parameters of black carp ( Mylopharyngodon piceus ) raised in lotic and lentic freshwater systems. LWT - Food Science and Technology, 90, 45-52.

Hernández-Herrero, M. M., Duflos, G., Malle, P., \& Bouquelet, S. (2003). Collagenase activity and protein hydrolysis as related to spoilage of iced cod (Gadus morhua). Food Research International, 36, 141-147.

Huff-Lonergan, E., \& Lonergan, S. M. (2005). Mechanisms of water-holding capacity of meat: The role of postmortem biochemical and structural changes. Meat Science, 71, 194-204.

Hughes, J., Oiseth, S., Purslow, P., \& Warner, R. (2014). A structural approach to understanding the interactions between colour, water-holding capacity and tenderness. Meat Science, 98, 520-532.

Kaale, L. D., \& Eikevik, T. M. (2013). A histological study of the microstructure sizes of the red and white muscles of Atlantic salmon (Salmo salar) fillets during 
superchilling process and storage. Journal of Food Engineering, 114, 242-248.

Kaale, L. D., \& Eikevik, T. M. (2014). The development of ice crystals in food products during the superchilling process and following storage, a review. Trends in Food Science \& Technology, 39, 91-103.

Kjærsgård, I. V., \& Jessen, F. (2003). Proteome analysis elucidating post-mortem changes in cod (Gadus morhua) muscle proteins. Journal of Agricultural \& Food Chemistry, 51, 3985-3991.

Li, T., Li, J., Hu, W., Chen, J., \& Li, H. (2014). Protein changes in post mortem large yellow croaker (Pseudosciaena crocea) monitored by SDS-PAGE and proteome analysis. Food Control, 41, 49-55.

Liu, D., Liang, L., Xia, W., Regenstein, J. M., \& Zhou, P. (2013). Biochemical and physical changes of grass carp (Ctenopharyngodon idella) fillets stored at -3 and $0{ }^{\circ} \mathrm{C}$. Food Chemistry, 140, 105-114.

Ofstad, R., Egelandsdal, B., Kidman, S., Myklebust, R., Olsen, R. L., \& Hermansson, A. M. (1996). Liquid loss as effected by post mortem ultrastructural changes in fish muscle: cod (Gadus morhua L.) and salmon (Salmo salar). Journal of the Science of Food \& Agriculture, 71, 301-312.

Ofstad, R., Olsen, R. L., Taylor, R., \& Hannesson, K. O. (2006). Breakdown of intramuscular connective tissue in cod (Gadus morhua L.) and spotted wolffish (Anarhichas minor O.) related to gaping. LWT - Food Science and Technology, $39,1143-1154$.

Papa, I., Alvarez, C., Verrezbagnis, V., Fleurence, J., \& Benyamin, Y. (1996). Post 
mortem release of fish white muscle alpha-actinin as a marker of disorganisation. Journal of the Science of Food \& Agriculture, 72, 63-70.

Pomponio, L., Lametsch, R., Karlsson, A. H., Costa, L. N., Grossi, A., \& Ertbjerg, P. (2008). Evidence for post-mortem m-calpain autolysis in porcine muscle. Meat Science, 80, 761-764.

Taylor, R. G., Fjaera, S. O., \& Skjervold, P. O. (2002). Salmon fillet texture is determined by myofiber-myofiber and myofiber-myocommata attachment. Journal of Food Science, 67, 2067-2071.

Toyohara, H. , \& Makinodan, Y. (1989). Comparison of calpain I and calpain II from carp muscle. Comparative Biochemistry \& Physiology B Comparative Biochemistry, 92, 577-581.

Tsuchiya, H., \& Seki, N. (1991). Action of calpain on $\alpha$-actinin within and isolated from carp myofibrils. Nippon Suisan Gakkaishi, 57, 1133-1139.

Wang, P. A., Martinez, I., \& Olsen, R. L. (2009). Myosin heavy chain degradation during post mortem storage of Atlantic cod (Gadus morhua L.). Food Chemistry, $115,1228-1233$.

Wu, G., Clerens, S., \& Farouk, M. M. (2014). LC MS/MS identification of large structural proteins from bull muscle and their degradation products during post mortem storage. Food Chemistry, 150, 137-144.

Wu, J., Lu, B., Du, M., Liu, G., Hara, K., Su, W., . . C Cao, M. (2008). Purification and characterization of gelatinase-like proteinases from the dark muscle of common carp (Cyprinus carpio). Journal of Agricultural \& Food Chemistry, 56, 2216- 
Xu, Y., Liu, D., Yang, H., Jie, Z., Liu, X., Regenstein, J. M., . . Peng, Z. (2016). Effect of calcium sequestration by ion-exchange treatment on the dissociation of casein micelles in model milk protein concentrates. Food Hydrocolloids, 60, 5966.

Zhang, Y., \& Ertbjerg, P. (2018). Effects of frozen-then-chilled storage on proteolytic enzyme activity and water-holding capacity of pork loin. Meat Science. 145, $375-382$.

Zou, L., Wan, J. Q., Zhong, Y. G., Li, J., \& Zhao, Y. F. (2014). Effect of cold-induced on quality of black carp fillet stored at controlled freezing-point. Advanced Materials Research, 941-944, 1045-1050. 


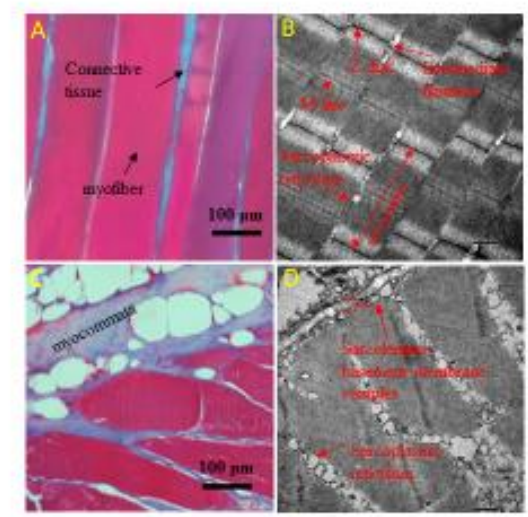

Fig.1. Representative micrographs of fresh black carp muscle. Light microscopic images of longitudinal section (A) and area containing myocommata (C); TEM images of showing myofibrils (B) and myofibril-sarcolemma-basement membrane attachment (D). 


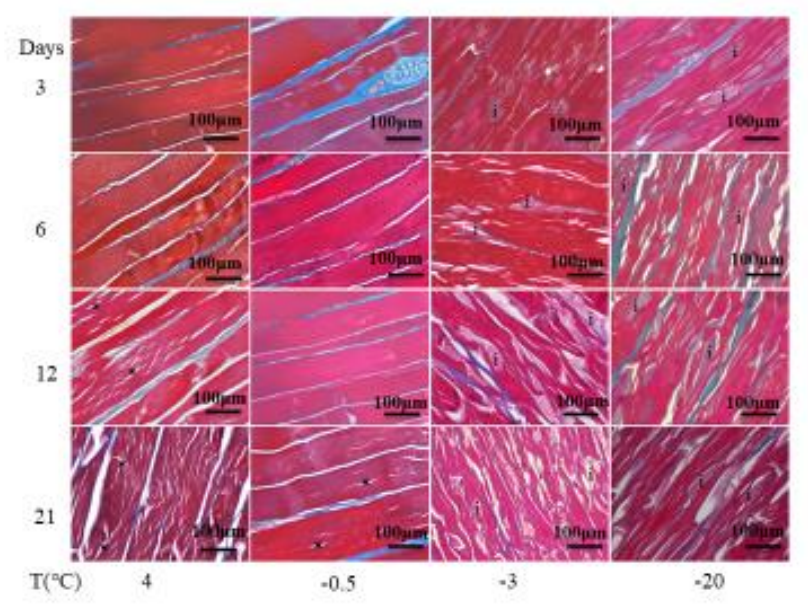

Fig.2. Representative light microscopic images of longitudinal section of black carp muscle stored at different temperatures. * - weakened or broken myofiber; i - ice crystal. 


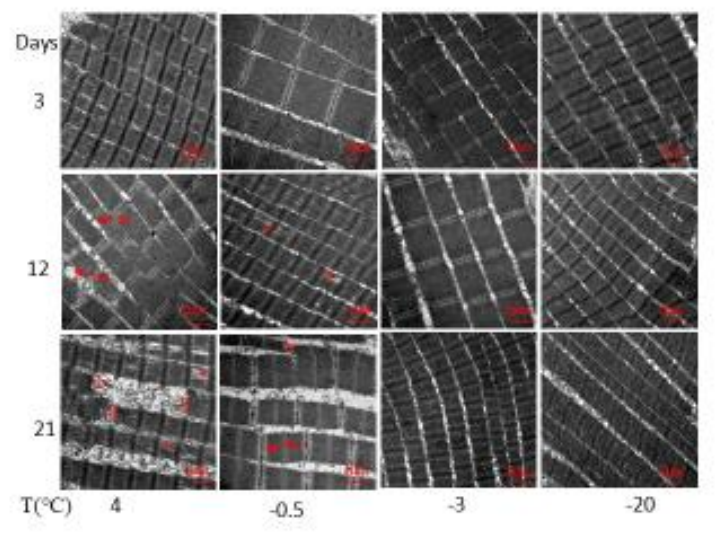

Fig.3. Representative TEM images of myofibrils of black carp muscle stored at different temperatures. * - weakened myofibril; b - broken myofibril; wZ - weakened Z-disk; sr - sarcoplasmic reticulum. 


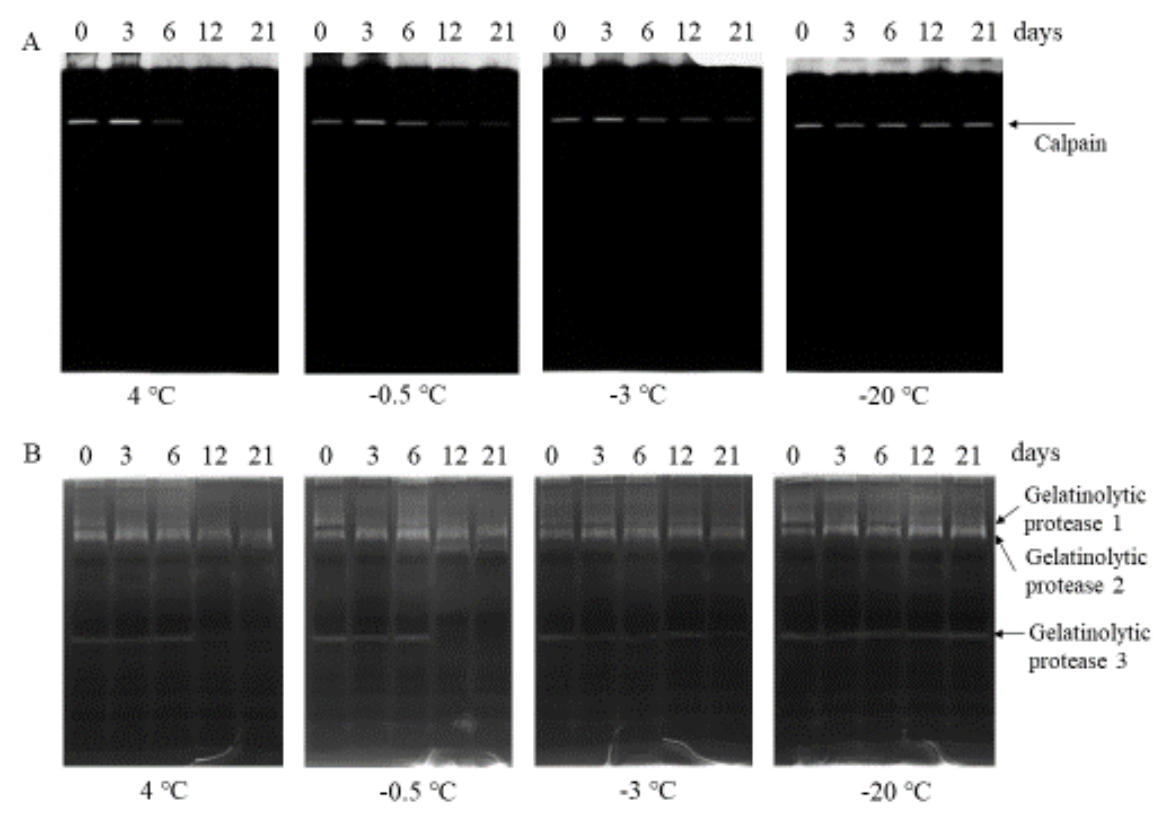

Fig.4. The casein zymography (A) and gelatin zymography (B) changes of black carp muscle during storage at different temperatures. 


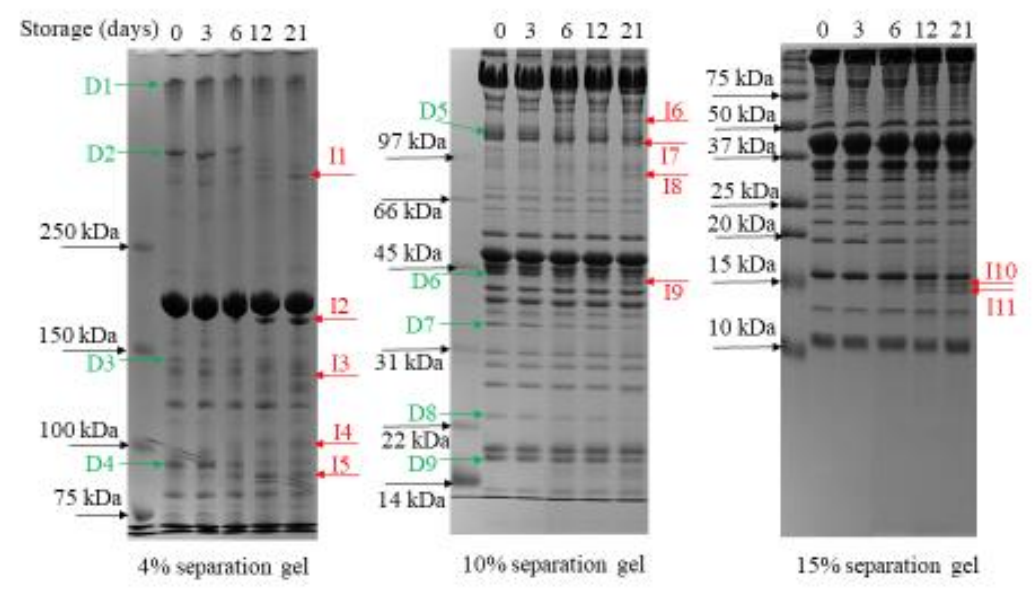

Fig.5. SDS-PAGE of protein extract of black carp muscle during storage at $4{ }^{\circ} \mathrm{C}$. D1D9 (marked as green) were bands regarded to be decreased during storage, and I1-I11 (marked as red) were bands regarded to be increased during storage. D1 - D9 \& I1 I11 were selected for further protein identification. Different concentrations of separation gel was used to better separate proteins over a wide range. 